\title{
SEISMIC ANALYSIS OF MULTISTORIED BUILDING WITH SETBACK IRREGULARITY USING TIME HISTORY ANALYSIS: BY MEANS OF INDIAN SEISMIC CODE
}

\author{
Huzefa Sarangkhedawala \\ Department of Civil \\ IES IPS, INDORE, M.P., INDIA
}

\author{
Rajesh Chaturvedi \\ Department of IT \\ IES IPS, INDORE, M.P., INDIA
}

\begin{abstract}
Irregularities are not avoidable in construction of buildings, however the behavior of structures with these irregularities during earthquake needs to be studied. Adequate precautions needs to be taken. A detailed study of structural behavior of the building with irregularities is essential for design and behavior. The performance of a high rise building during strong earthquake motion depends on the distribution of stiffness, strength and mass along both the vertical and horizontal directions. If there is discontinuity in stiffness, strength and mass between adjoining storeys of a building then such a building is known as irregular building. The present study focuses on the performance and behavior of regular and vertical irregular $\mathbf{G + 2 0}$ reinforced concrete $(\mathbf{R C})$ building under seismic loading. Type of vertical irregularities namely setback is considered in the study. Total four models are modeled in which one is regular and three are irregular and seismic analysis is carried out using time history analysis method. The carpet area or sellable area of all the four models are to be kept same and comparison has been made on the basis of area. Different seismic responses like storey drift, storey displacement, and overturning moment are obtained. By using these responses, a comparative study has been made between regular and irregular buildings. The result remarks the conclusion that, a building structure with setback irregularity provides instability during seismic loading. From the study it is recommended that analysis of multistoried RCC building using time history analysis becomes necessary to ensure safety against earthquake force
\end{abstract}

Keywords - Design basis earthquake, Story drift, Story Displacement, Base Shear, Overturning Moment, Time History analysis, Seismic assessment.

\section{INTRODUCTION}

Earthquake is most distressing natural causing loss of life, loss of economy, destruction and damage to infrastructures. Now a day's most of the building structures are made of Reinforced cement concrete, and such structures have the potential to cause many deaths and injuries along with extensive property damage that alone earthquake cannot do, which has been seen in earlier earthquake events like Latur earthquake (1993),Bhuj earthquake (2001), Indian Ocean Earthquake (2004), Kashmir earthquake and Nepal earthquake. Since earthquake forces are random in nature and prediction of future earthquake may not be possible, thus prevention of these structures from earthquake damage has become progressively important in recent years.

Severe earthquakes happen rarely. Even though it is technically possible to design and build structures for these earthquake events, it is for the most part considered uneconomical to do so. The objective of the seismic design is to constraint the damage in a structure to a worthy sum. The structures designed in such a way that should have the capacity to resist minor levels of earthquake without damage, withstand moderate levels of earthquake without structural damage, yet probability of some non-structural damage, and withstand significant levels of ground motion without breakdown, yet with some structural and in addition nonstructural damage. This paper presents non-linear

Dynamic analysis of multistoried building $\mathrm{G}+20$ designed as per Indian code IS 456:2000 and IS 13920:2016. The objective of this study is to evaluate the seismic performance of building for DBE. The results are presented in terms Story drift, Story Displacement, Base Shear, Overturning Moment.

\section{CASE STUDY OF THE BUILDING}

A four models of G+20 story RCC building is considered to illustrate the analysis and design of the frame. The typical plan dimension of the model 1 which is regular model is having $\mathrm{X}$ direction length: $36 \mathrm{~m}$ and $\mathrm{Y}$ direction width: $36 \mathrm{~m}$ which is divided into 6 and 6 bays respectively. Total height of the building is $85 \mathrm{~m}$ with $5 \mathrm{~m}$ height of first story and $4 \mathrm{~m}$ of upper stories. The plan and elevation of the regular building

is shown in Fig.1 and Fig 2. Model two, three and four are irregular models having $\mathrm{X}$ direction length: $46.4 \mathrm{~m}$ and $\mathrm{Y}$ direction width: $46.4 \mathrm{~m}$ which is divided into 8 and 8 bays respectively. The plan and elevation of the regular building is shown in Fig.3 and Fig 4.

The structure is design according to Indian code IS 456:2000 for seismic zone IV for soil Class II. Earthquake loading was combined with gravity load (DL +0.5 LL). Dead load includes self-weight of the members, load of exterior $125 \mathrm{~mm}$ thick concrete block $(3.584 \mathrm{kN} / \mathrm{m})$ and live loads $(3 \mathrm{kN} / \mathrm{m} 2$ floor and $1.5 \mathrm{kN} / \mathrm{m} 2$ on roof).

\section{MODELING PARAMETERS}

The design of the structural concrete members follows the Indian National Standard of Plain and Reinforced Concrete code of Practice. The compressive strength of the concrete in the frame is $35 \mathrm{MPa}$, where the design steel yield strength is $500 \mathrm{MPa}$.

Model Specifications

- Model A consist of 6x6 bay up to top floor. 
- Model B consist of $8 \times 8$ bay up to 7 floor. $6 x 6$ bay up to 14 floor and $4 \times 4$ bay up to 21 floor (centre position).

- Model C consist of $8 \times 8$ bay up to 7 floor. $6 \times 6$ bay up to 14 floor and 4x4 bay up to 21 floor (corner position).

- Model D consist of 8x8 bay up to 7 floor. 6x6 bay up to 14 floor and $4 \times 4$ bay up to 21 floor (edge position).
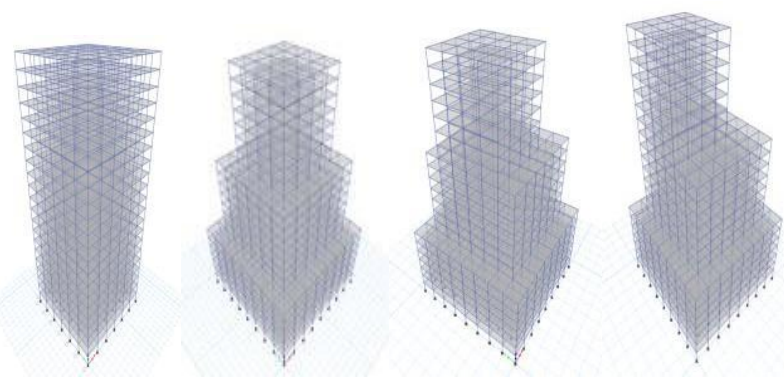

Model 1

Model 3

Model 4

\section{Regular RC Building}

Twenty-One story regular reinforced concrete buildings. The beam length in $(\mathrm{x})$ transverse direction is $36 \mathrm{~m}$ and in $(\mathrm{y})$ longitudinal direction $36 \mathrm{~m}$. Figure 3.1 shows the plan of the building having six bays in $\mathrm{x}$-direction and six bays in $\mathrm{y}$ direction. Story height of each building is assumed $4 \mathrm{~m}$ and story height of base story is $5 \mathrm{~m}$. Figure shows the frame (A-

A) and (01-01) of the twenty-one story RC building respectively.

MODEL 1

\begin{tabular}{|l|l|l|}
\hline Story & Column & Beam \\
\hline Base & $650 \times 650$ & $300 \times 400$ \\
\hline $2-7$ & $600 \times 600$ & $250 \times 300$ \\
\hline $8-14$ & $500 \times 500$ & $250 \times 300$ \\
\hline $15-21$ & $450 \times 450$ & $250 \times 300$ \\
\hline
\end{tabular}

Irregular RC Building

Twenty-One story irregular reinforced concrete buildings. The beam length in $(\mathrm{x})$ transverse direction is $6 \mathrm{~m}$ and in $(\mathrm{y})$ longitudinal direction $6 \mathrm{~m}$. Figure 3.5 shows the plan of the three buildings having six bays in $\mathrm{x}$-direction and six bays in $\mathrm{y}$-direction from 1 to 7 story, four bays in $\mathrm{x}$-direction and four bays in $\mathrm{y}$-direction from 8 to 14 story, two bays in $\mathrm{x}$ direction and two bays in y-direction from 15 to 21 story. Story height of each building is assumed $4 \mathrm{~m}$ and base height is $5 \mathrm{~m}$. Figure 3.6, 3.8, and 3.10 shows frame (01-01) and (0606) of the twenty-one story irregular RC buildings respectively. Figure 3.7, 3.9, and 3.11 shows frame (A-A) and (F-F) of the twenty- one story irregular reinforced concrete building respectively.

\section{MODEL 2}

\begin{tabular}{|c|c|c|}
\hline Story & Column & Beam \\
\hline Base & $750 \times 750$ & $350 \times 650$ \\
\hline $2-7$ & $650 \times 650$ & $350 \times 650$ \\
\hline $8-14$ & $650 \times 650$ & $375 \times 650$ \\
\hline $15-21$ & $650 \times 650$ & $350 \times 650$ \\
\hline
\end{tabular}

MODEL 3

\begin{tabular}{|c|c|c|}
\hline Story & Column & Beam \\
\hline Base & $800 \times 800$ & $350 \times 600$ \\
\hline $2-7$ & $700 \times 700$ & $350 \times 650$ \\
\hline $8-14$ & $700 \times 700$ & $375 \times 650$ \\
\hline $15-21$ & $600 \times 700$ & $350 \times 650$ \\
\hline
\end{tabular}

MODEL 4

\begin{tabular}{|c|c|c|}
\hline Story & Column & Beam \\
\hline Base & $800 \times 800$ & $350 \times 650$ \\
\hline $2-7$ & $700 \times 750$ & $350 \times 650$ \\
\hline $8-14$ & $650 \times 750$ & $400 \times 650$ \\
\hline $15-21$ & $650 \times 750$ & $350 \times 650$ \\
\hline
\end{tabular}

\section{ACCElEROGRAM USED FOR PRESENT STUdy}

The 6 accelerogram of scaled time history data with actual time history data mentioned. The scaled time history data used for analysis. Each group then scaled to same level of intensity, due to scaling the PGA of all 6 Time history data approximate equal to $0.360 \mathrm{~g}$. Which shows the Design Basis Earthquake (DBE). The difference between the time histories, Shown by

the distance between the P-wave, S-wave and Surface wave, the duration of earthquake, time of an earthquake. The above effects considered in this study for the performance evaluation for (PGA $=0.36 \mathrm{~g}$ approximate) Design Basis Earthquake (DBE) and then scaled to (PGA=0.34g approximate).

Table -1 Time history data

\begin{tabular}{|c|c|c|c|c|c|}
\hline \multicolumn{6}{|c|}{ TIME HISTORY DATA INFORMATION } \\
\hline SR NO. & NAME & STATION & DATE & INTENSITY & PGA \\
\hline 1 & Loma prieta & Hollister City & 18-10-1989 & 6.93 & 0.216 \\
\hline 2 & Northridge -01 & $\begin{array}{l}\text { Converter staEast } \\
\text { sylmar }\end{array}$ & 17-01-1994 & 6.69 & 0.448 \\
\hline 3 & Chuetsu oki & $\begin{array}{c}\text { Niigata Nishi Kaba } \\
\text { district }\end{array}$ & 16-07-2007 & 6.8 & 0.133 \\
\hline 4 & Tmperial Valley -06 & Aeropuerto Mexicali & 15-10-1979 & 6.53 & 0.306 \\
\hline 5 & Supperstition Hills & Parachute Test Site & 24-11-1987 & 6.54 & 0.431 \\
\hline 6 & Imperical Valley & Holtville Post Office & 15-10-1979 & 6.55 & 0.571 \\
\hline
\end{tabular}

\section{CENTRE OF MASS AND CENTRE OF RIGIDITY}

The center of mass and rigidity of model 1 lies on same point because it is regular building. The center of mass and rigidity differs for remaining 3 models as they are irregular in shape, which is shown below in terms of eccentricity.

Table -2 Centre of mass and rigidity values. 
International Journal of Engineering Applied Sciences and Technology, 2020

Vol. 4, Issue 11, ISSN No. 2455-2143, Pages 92-97

Published Online March 2020 in IJEAST (http://www.ijeast.com)

\begin{tabular}{|c|c|c|c|c|c|}
\hline & \multirow{2}{*}{ Story } & XCM & YCM & XCR & YCR \\
\cline { 3 - 6 } & & $\mathbf{m}$ & $\mathbf{m}$ & $\mathbf{~ m}$ & $\mathbf{m}$ \\
\hline \multirow{3}{*}{$\begin{array}{c}\text { MODEL } \\
2\end{array}$} & Story21 & 23.2 & 23.2 & 23.18 & 23.17 \\
\cline { 2 - 6 } & Story14 & 23.2 & 23.2 & 23.11 & 23.08 \\
\cline { 2 - 6 } & Story7 & 23.2 & 23.2 & 23.2 & 23.2 \\
\hline \multirow{3}{*}{$\begin{array}{c}\text { MODEL } \\
3\end{array}$} & Story21 & 17.4 & 29 & 18.95 & 27.43 \\
\cline { 2 - 6 } & Story14 & 22.97 & 23.43 & 23.16 & 23.25 \\
\cline { 2 - 6 } & Story7 & 23.2 & 23.2 & 23.2 & 23.2 \\
\hline \multirow{3}{*}{$\begin{array}{c}\text { MODEL } \\
4\end{array}$} & Story21 & 17.4 & 29.21 & 18.89 & 27.56 \\
\cline { 2 - 6 } & Story14 & 23 & 23.64 & 23.18 & 23.38 \\
\cline { 2 - 6 } & Story7 & 23.2 & 23.2 & 23.2 & 23.2 \\
\hline
\end{tabular}

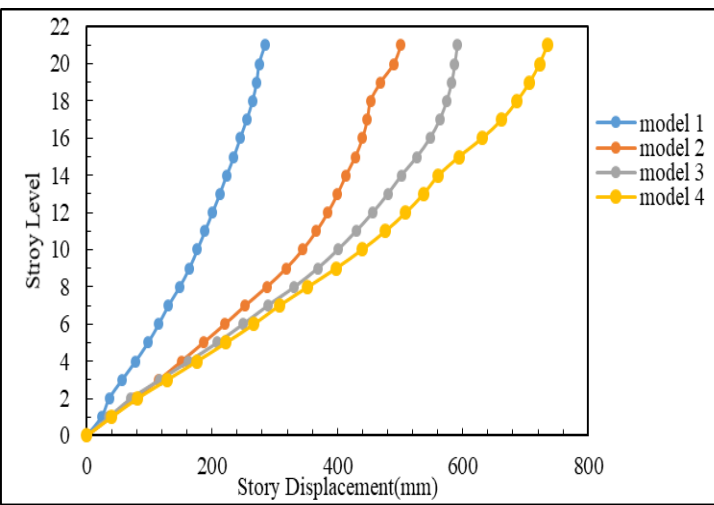

\section{STORY SHEAR}

Story shear of concentric model at $21^{\text {st }}$ floor is 2.26 times more as compared to regular model, $14^{\text {th }}$ floor story shear is 2.53 times more than that of regular model and $7^{\text {th }}$ floor story shear is 3.13 times more as compared to regular model. Story shear of semi eccentric model at 21 st floor is 2.40 times more as compared to regular model, $14^{\text {th }}$ floor story shear is 2.6 times more than that of regular model and $7^{\text {th }}$ floor story shear is 3.32 times more as compared to regular model. Story shear of eccentric model at 21 st floor is 2.65 times more as compared to regular model, $14^{\text {th }}$ floor story shear is 2.72 times more than more as compared to regular model that of regular model and $7^{\text {th }}$ floor story shear is 3.55 times.

Following table represents the story shear at following floors for all models.

Table -3 Story shear values.

\begin{tabular}{|c|c|c|c|c|}
\hline & \multicolumn{4}{|c|}{ STORY } \\
\hline & $\begin{array}{c}\text { Regular } \\
\text { FLOOR }\end{array}$ & $\begin{array}{c}\text { Concentri } \\
\text { Model(kN) } \\
\text { c } \\
\text { Model(kN) }\end{array}$ & $\begin{array}{r}\text { Eccentric } \\
\text { Model(kN) }\end{array}$ & $\begin{array}{r}\text { Eccentric } \\
\text { Model(kN) }\end{array}$ \\
\hline $21^{\text {stfloor }}$ & $\mathbf{7 5 2 . 9 5}$ & $\mathbf{1 7 0 8 . 3 9}$ & $\mathbf{1 8 0 8 . 2 5}$ & $\mathbf{1 9 9 0 . 1 4}$ \\
\hline $\begin{array}{c}14^{\text {th }} \\
\text { floor }\end{array}$ & 5321.21 & 13509.09 & 13799.93 & 14505.84 \\
\hline $7^{\text {th }}$ floor & 7192.31 & 22983.68 & 23887.25 & 24795.38 \\
\hline Total & 7648.87 & 25167.82 & 26081.58 & 27016.43 \\
\hline
\end{tabular}

\section{RESULT AND DISCUSSION}

a) Story Displacement

Fig. 1. Story VS Maximum displacement for different Time History Data for all models

When seismic analysis is performed on software (ETABS) with a particular time history data and on comparing between different model it is found that in model $\mathrm{D}$ at $7^{\text {th }}$ floor story displacement is 2.35 times, at $14^{\text {th }}$ floor it is 2.51 times and at $21^{\text {st }}$ floor it is 2.58 times greater as compared to model A.

It is found that in model $\mathrm{C}$ at $7^{\text {th }}$ floor story displacement is 2.21 times, at $14^{\text {th }}$ floor it is 2.24 times and at $21^{\text {st }}$ floor it is 2.07 times greater as compared to model A.

It is found that in model B at $7^{\text {th }}$ floor story displacement is 1.94 times, at $14^{\text {th }}$ floor it is 1.85 times and at $21^{\text {st }}$ floor it is 1.76 times greater as compared to model $\mathrm{A}$.

It is found that Eccentric model (model D) has maximum displacement, Semi Eccentric Model (model C) has moderate displacement and Concentric Model (model B) has minimum displacement as compared to Regular Model (model A).

\section{b) Story Drift}

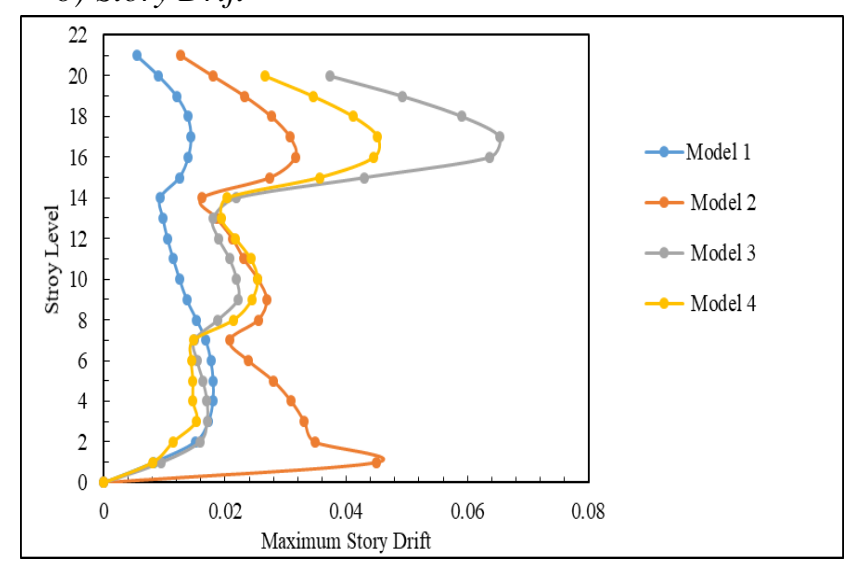

Fig. 2. Story VS Maximum Drift for different Time History Data for all models

When seismic analysis is performed on software (ETABS) with a particular time history data and on comparing between different model it is found that in model $\mathrm{D}$ at $7^{\text {th }}$ floor story drift ratio is 0.88 times, at $14^{\text {th }}$ floor it is 2.35 times and at $21^{\text {st }}$ floor it is 4.64 times greater as compared to model $\mathrm{A}$ as shown in figure 4.2

It is found that in model $\mathrm{C}$ at $7^{\text {th }}$ floor story drift ratio is 0.87 times, at $14^{\text {th }}$ floor it is 2.19 times and at $21^{\text {st }}$ floor it is 3.53 times greater as compared to model $\mathrm{A}$ as shown in figure 4.3

It is found that in model B at $7^{\text {th }}$ floor story drift ratio is 1.23 times, at $14^{\text {th }}$ floor it is 1.74 times and at $21^{\text {st }}$ floor it is 2.35 times greater 


\section{International Journal of Engineering Applied Sciences and Technology, 2020 \\ Vol. 4, Issue 11, ISSN No. 2455-2143, Pages 92-97 \\ Published Online March 2020 in IJEAST (http://www.ijeast.com)}

as compared to model $\mathrm{A}$ as shown in figure 4.4

It is found that Eccentric model (model D) has maximum drift, Semi Eccentric Model (model C) has moderate drift and Concentric Model (model B) has minimum drift as compared to Regular Model (model A) as shown in figure 4.10

c) Overturning Moment

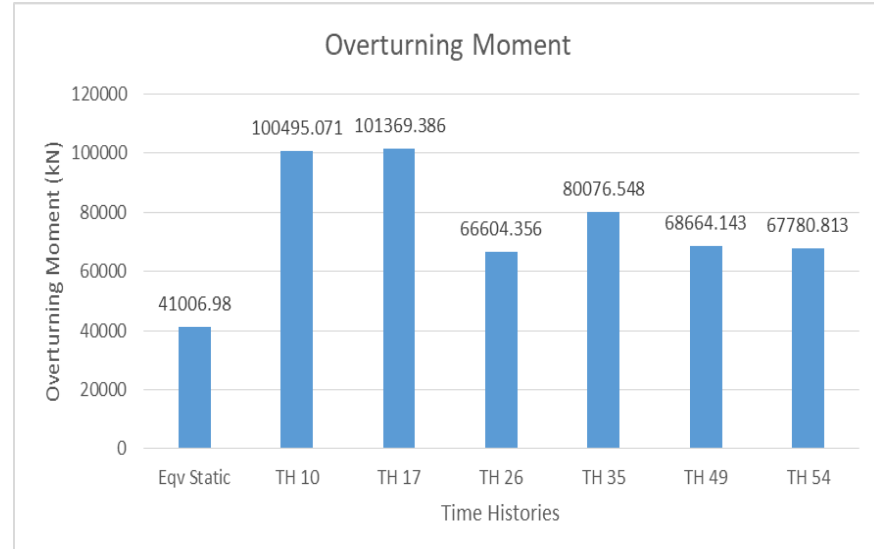

Fig. 3. Overturning Moment VS Different Time History Data for Model A

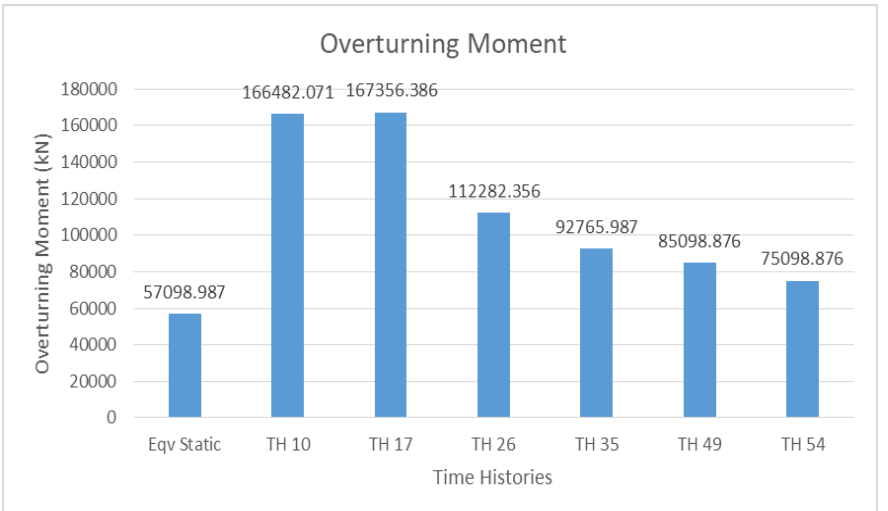

Fig. 4. Overturning Moment VS Different Time History Data for Model B

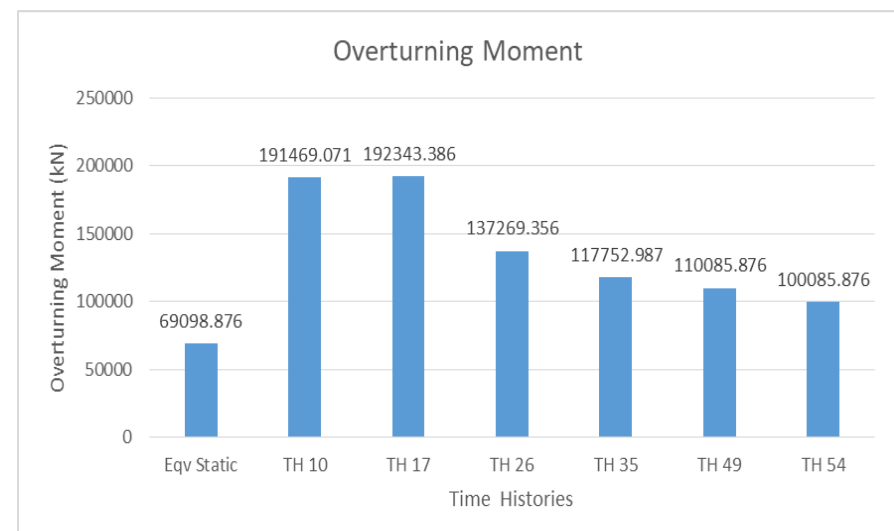

Fig. 5. Overturning Moment VS Different Time History Data for Model C

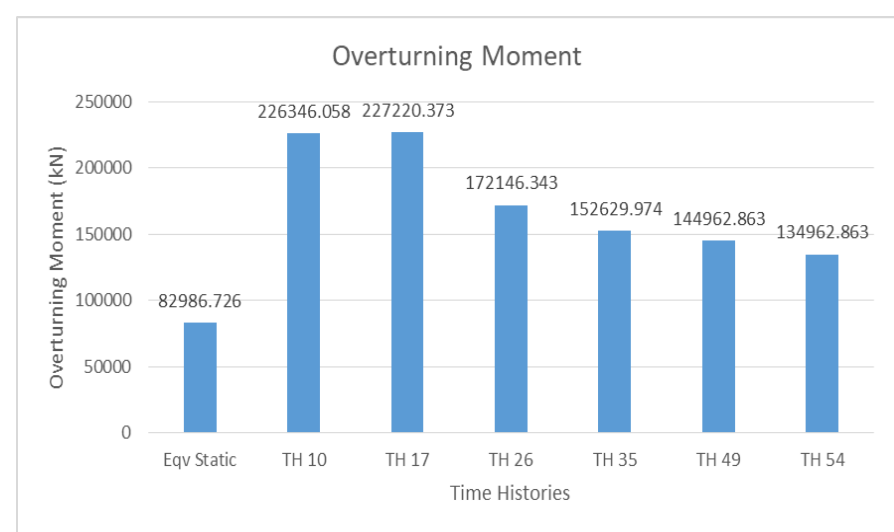

Fig. 6. Overturning Moment VS Different Time History Data for Model D

When seismic analysis is performed on software (ETABS) with a particular time history data and when compared between different models it is found that Model D has maximum overturning moment and which is $\mathbf{1 1 8 . 2 \%}$ compared toregular model.

It is found that Model C has overturning moment which is $\mathbf{7 5 . 0 5 \%}$ compared to regular model.

It is found that Model B has minimum overturning moment and which is $\mathbf{4 4 . 1 4 \%}$ compared to regular model.

\section{d) Base Shear}

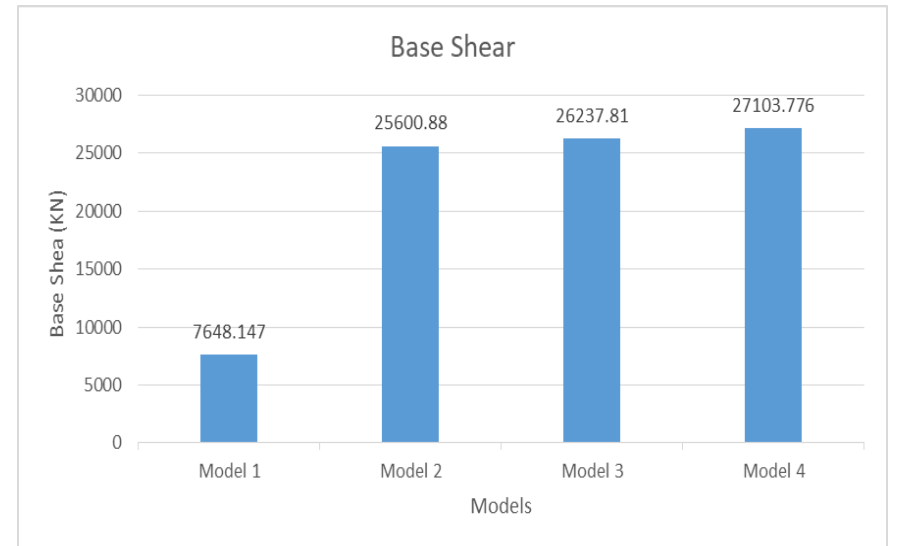

Fig. 7. Base Shear VS Different Time History Data for all Models

When seismic analysis is performed on software (ETABS) with a particular time history data and when compared between different models it is found that Model D has maximum base shear and which is 3.54 times more than model A.

It is found that Model $\mathrm{C}$ has base shear 3.43 times more than model A.

It is found that Model B has minimum base shear 3.34 times more than model A.

\section{e) Costing of Steel and Concrete}

Table - 4 represent the costing of concrete and steel required for whole construction purpose of all models. 
International Journal of Engineering Applied Sciences and Technology, 2020

Vol. 4, Issue 11, ISSN No. 2455-2143, Pages 92-97

Published Online March 2020 in IJEAST (http://www.ijeast.com)

\begin{tabular}{|c|c|c|c|c|c|}
\hline & \multirow{2}{*}{ CONCRETE } & \multirow{2}{*}{ STEEL } & \multicolumn{2}{|c|}{ COSTING } & \\
\cline { 4 - 6 } MODEL & & & CONCRETE & STEEL & TOTAL \\
\hline & cubic meter & $\mathrm{kg}$ & $\mathrm{Rs}$ & $\mathrm{Rs}$ & $\mathrm{Rs}$ \\
\hline model 1 & 2587.1 & 395867.81 & 15406180.5 & 29880102.3 & 45286282.8 \\
\hline model2 & 4062.89 & 442560.43 & 24194509.95 & 33404461.26 & 57598971.21 \\
\hline model 3 & 4393.36 & 526154.29 & 26162458.8 & 39714125.81 & 65876584.61 \\
\hline model 4 & 4516.3 & 610976.35 & 26894566.5 & 46116494.9 & 73011061.4 \\
\hline
\end{tabular}

As per Schedule of Rates (SOR) of MPPWD for year 2014 with an increase of $20 \%$ rate in concrete and $15 \%$ increase in steel, rate of concrete per cubic meter is 5955/- and rate for steel is 75.48/- per $\mathrm{kg}$.

We have observed that total costing of concentric model is increased by $1,23,12,689 /$ - rupees, Semi Eccentric model is increased by $2,05,90,301 /$ - rupees and Eccentric model is increased by $2,77,24,778 /-$ rupees as compared to Regular model.

\section{CONCLUSION}

The eccentric model has maximum story drift which is $262.42 \%$ more than regular model, semi eccentric model has story drift which is $151 \%$ more than regular model and concentric model has minimum story drift which is $149 \%$ more than regular model.

On analyzing the model with different time histories, eccentric model has maximum story displacement which is $158.80 \%$ more than regular model, semi eccentric model has story displacement which is $108.4 \%$ more than regular model and concentric model has minimum story displacement which is $76.62 \%$ more than regular model.

Among the different arrangement of irregular model (model 2) which is concentric model gives the best results.

The overturning moment of eccentric model is $102.37 \%$ more as compared to regular model, semi eccentric model is $68.5 \%$ more as compared to regular model and concentric model is $39.24 \%$ more than that of regular model.

As the stiffness decreases the responses of the structure increases.

Loma Prieta time history which was occurred at Hollister City Hall in year 1989 gives the maximum responses to regular and irregular models.

As we have compared costing of all the models we came to a conclusion that costing of concentric model is increased by $27.81 \%$, costing of semi eccentric model is increased by $45.46 \%$ and costing of eccentric model is increased by $61.22 \%$ as compared to regular model.

From the result, it was observed that there is increase in steel and concrete for the building with setback irregularity.

As time history is realistic method, used for seismic analysis, it provides a better check to safety of structures analyzed and designed by method specified by IS code.

\section{REFERENCE}

1. Anvesh, N., Yajdani, S., \& Pawan, k. (2015). "Effect of mass irregularity on reinforced concrete Structure using ETABS". International Journal of Innovative Researchin Science, Engineering and Technology (IJIRSET), 4(10).

2. Arvindreddy, R. J., \& Fernandes, M. R. (2015). "Seismic analysis of RC regular and irregular frame structure". International Research Journal of Engineering and Technology (IRJET), 2(05).

3. Bansal, H. (2014). Gagandeep. "SEISMIC ANALYSIS AND DESIGN OF VERTICALLY IRREGULAR RC BUILDING FRAMES", 3(8).

4. Khan, P. I., \& Dhamge, N. R. (2016). "Seismic analysis of multistoried RCC building due to mass Irregularity".

5. Konakalla, R. D., \& Raparla, H.B. (2012). "Response Study of Multi-storied Buildings with Plan Irregularity Subjected to Earthquake and Wind Loads using Linear Static Analysis". Architecture Research, 2, 20-26

6. Konakalla, R., Chilakapati, R. D., \& Raparla, H. B. (2014). "Effect of Vertical Irregularity in Multistoried Buildings under Dynamic Loads Using Linear Static Analysis". Int J Educ Appl Res, 5(2), 29-34.

7. Khudhair, S. Y., \& Mouli, D. C. (2017). "Study of the Vertical irregularities in Tall RC Structures under Lateral Load". International Journal of Engineering Science, 11129.

8. Mandloi, P., \& Chaturvedi,R. (2018). "Seismic analysis of vertical irregular buildings with time history analysis". Journal of Meachanical and Civil Engineerng (IOSR_JMCE), 14(4).

9. Mahesh, M. S., \& Rao, M. D. B. P. (2014). "Comparison of analysis and design of regular and irregular configuration of multistory building in various seismic zones and various types of soils using ETABS and STAAD”. Journal of Mechanical and civil Engineering (IOSR-JMCE), 11(6).

10. Patil, A. S., \& Kumbhar, P. D. (2013). "Time history analysis of multistoried rcc buildings for different seismic intensities". International journal of Structural and Civil Engineering Research, 2(3), 194-201.

11. Poncet, L., \& Tremblay, R. (2004, August). "Influence of Mass irregularity on The Seismic Design and Performance of Multi-Storey Braced Steel Frames". In 13th world conference on earthquake engineering, Vancover, BC, Canada, paper (No.2896).

12. Rahman, S. A. A. A., \& Deshmukh, G. (2013). "Seismic response of vertically irregular RC frame with stiffness irregularity at fourth floor". Nanded, India, IJETAE, 3.

13. Sayyed, O., Kushwah, S. S., \& Rawat, A. (2017). "Effect of Infill and Mass Irregularity on RC Building under Seismic Laoding”. International Journal of Engineering and Technology (IRJET), 4(02).

14. Sayyed, O., Kushwah, S. S., \& Rawat, A. (2017). "Seismic Analysis of Vertical Irregular RC Building with Stiffness and Setback Irregularities". IOSR journal of Mechanical and Civiil Engineering. 14(1). 
15. Varadharajan, S., Sehagal, V. K., \& Saini, B. (2012). "Review of different structural irregularities in buildings". Journal of structural engineering, 39(5), 393-418

16. Verma, V., \& Vyas, J. N. (2018). "Seismic analysis and comparision of vertical irregular building cases using response spectrum method". International Journal of Application or Innovation in Engineering and Management (IJAIEM), 7(8). 